\title{
ПОКАЗНИКИ СТРУКТУРИ УРОЖАЮ ЗЕРНА КУКУРУДЗИ ЗАЛЕЖНО ВІД ГІБРИДУ, НОРМИ ДОБРИВ ТА МІКРОДОБРИВА В УМОВАХ ЛІСОСТЕПУ ЗАХІДНОГО
}

\begin{abstract}
Анотація. Дослідженнями встановлено та результатами математичного аналізу підтверджено вплив особливостей гібриду кукурудзи, норми добрив та мікродобрива на показники структури урожаю: висоту рослин, висоту кріплення качана, кількість рядів зерен в качані та кількість зерен в ряді. Аналіз за проведеним тестом Дункана показав істотну різницю за показниками структури рослин у розрізі гібридів, оскільки значення всіх біометричних показників знаходились у різних гомогенних групах. Зафіксовано розподіл по двох гомогенних групах показників за факторами норм добрив і мікродобрива, відповідно норми 150 та 200 кг/га належали до першої і 250 та 300 - до другої гомогенної групи. Аналогічну тенденцію відмічено при розподілі норм мікродобрив. Досліджувані нами фактори на висоту рослин не значно впливали, проте у всіх досліджуваних гібридів на більших фонах добрив (250-300 кг/га) та при вищих нормах мікродобрив (2-3 л/га) спостерігалась тенденщія до зміни показника у сторону збільшення залежно від гібриду і варіанту на 16-21,9 см. Досліджувані нами гібриди характеризувались значною висотою кріплення качана - в межах 95,2 -121,1 см. Максимальні показники кількості рядів зерен 16,8-16,9 шт і кількості зерен в ряді качана кукурудзи 39,2 та 39,1 шт були на варіантах норми добрив 300 кг/га та мікродобрива 2 і 3 л/га.
\end{abstract}

Ключові слова: кукурудза, висота рослин, висота кріплення качана, кількість рядів в качані, кількість зерен в ряду.

Ivanyshyn Alexander

State Agrarian and Engineering University in Podilia

\section{INDICATORS OF THE MAIZE YIELD STRUCTURE DEPENDING ON THE HYBRID, THE RATE OF FERTILIZERS AND MICROFERTILIZERS IN THE CONDITIONS OF THE WESTERN FOREST-STEPPE}

Summary. To determine the influence of fertilizer and microfertilizer application rates on the formation of yield structure indicators in the cultivation of maize hybrids of different maturity groups. To study the biometric parameters of maize hybrids used a laboratory method, to assess the reliability of the results on individual indicators - the method of mathematical statistics. The research established and the results of mathematical analysis confirmed the influence of the features of the maize hybrid, fertilizer rates and microfertilizers on yield structure indicators: plant height, height of cob attachment, number of grains rows in the cob and number of grains in a row. Analysis by Duncan's test showed a significant difference in plant structure in terms of hybrids, as the values of all biometric indicators were in different homogeneous groups. The distribution of indicators by two homogeneous groups by factors of fertilizer and microfertilizer norms was recorded, respectively the norms of 150 and $200 \mathrm{~kg} / \mathrm{ha}$ belonged to the first and 250 and 300 - to the second homogeneous group. A similar tendency was observed in the distribution of microfertilizers. The factors studied by us did not significantly affect the height of plants, but in all studied hybrids on larger fertilizers $(250-300 \mathrm{~kg} / \mathrm{ha})$ and at higher rates of microfertilizers $(2-3 \mathrm{l} / \mathrm{ha}$ ) there was a tendency to change in the direction of increase depending on hybrid and variant by $16-21.9 \mathrm{~cm}$. The hybrids studied by us were characterized by a significant height of the fork attachment - in the range of $95.2-121.1 \mathrm{~cm}$. The maximum number of grains rows 16.8-16.9 pieces and the number of grains in a row of cobs maize 39.2 and 39.1 were on the variants of fertilizer rates of $300 \mathrm{~kg} /$ ha and microfertilizers 2 and 3 l/ha.

Keywords: maize, plant height, fork attachment height, number of rows in the cob, number of grains in a row.

$\Pi$ остановка проблеми. Аграрний сектор світової економіки в останні роки все більше уваги приділяе вирощуванню кукурудзи, площі якої становлять $20 \%$ у структурі ріллі та забезпечує понад $30 \%$ валового збору зернової маси. В результаті цього, дана культура займає лідируючі позищії серед інших сільськогосподарських культур. Останнім часом ми спостерігаємо тенденщію до зміни погодно-кліматичних умов, тому технології вирощування кукурудзи в умовах зони потребують удосконалення. Актуальними є питання застосування макро- та мікродобрив, зокрема, норм їх застосування. Важливим аспектом $є$ підбір гібриду за групою стиглості та продуктивністю в конкретних грунтово-кліматичних умовах вирощування. До основних біо- метричних показників та показників структури врожаю кукурудзи відносяться: висота кріплення качана, кількість рядів зерен та зерен в ряду. Важливе значення має і висота рослин, оскільки цей показник визначає ріст і розвиток рослин. Ці показники значно залежать від генетичного потенціалу, проте агротехнічні заходи теж можуть мати істотний вплив на формування продуктивності гібридів кукурудзи.

Аналіз останніх досліджень та публікацій. Зміна погодно-кліматичних умов, попит на світовому ринку і висока рентабельність кукурудзи роблять цю культуру привабливою для виробничників [1]. Держава споживає удвічі менше зерна кукурудзи, ніж експортує, за останні декілька років експорт кукурудзи збільшився 
у 7 разів [2]. За виробництвом зерна кукурудза сьогодні входить у п'ятірку світових лідерів [3] Тому проблема вдосконалення елементів агротехніки вирощування культури $є$ актуальною. Одними із найбільш дієвих чинників на продуктивність кукурудзи є удобрення та підбір гібриду для конкретних грунтово-кліматичних умов.

Мікроелементи беруть участь у всіх життевоважливих процесах, таких як фотосинтез, дихання, окислювально відновлювальні процеси, ферментативна діяльність, нуклеїновий та білковий обмін, синтез вітамінів, речовин росту, окрім того регулюють стан протоплазми, надходження іонів [4]. Всі ці процеси впливають на формування показників структури урожаю.

Спостереження Сатановської І.П. вказують на те, що найбільший приріст висоти рослин у фразі молочно-воскової стиглості зерна кукурудзи відбувався при проведенні позакореневого підживлення мінеральним добривом «Еколист» багатокомпонентний та його поєднання 3 «Емістимом С» на фроні передпосівної обробки насіння стимулятором росту "Емістим С» [5]. На думку співробітників Інституту зрошуваного землеробства Лавриненка Ю.О., Гожа О.А. та ін. одним із головних фракторів, які визначають ріст рослин у висоту все ж є генетичний, тобто параметри гібриду [6; 7]. Дослідження Паламарчука В.Д. вказують на те, що застосування бактеріального препарату «Біомаг» не впливало на зміну висоти кріплення продуктивних качанів кукурудзи [8]. Згідно результатів досліджень Мазура В.А, Циганської O.I., Шевченко Н.В., передпосівна обробка насіння мікробіологічним препаратом «Поліміксобактерин» та позакореневі підживлення мікродобривом «Мікро-Мінераліс» (кукурудза) i біостимулятором росту «Стимпо» збільшують висоту рослин середньораннього гібриду кукурудзи Арія в умовах Лісостепу правобережного як за окремого використання, так і у комплексі. У фразі молочної стиглості висота рослин за використання даних препаратів зростає від 208 до 218 см [9]. Багатченко В.В. Таганцова М.М., Стефківська Ю.Л. аналізуючи свої дослідження вказують, що на насіннєву продуктивність батьківських компонентів гібридів кукурудзи має вплив густота стояння рослин. При меншій густоті стояння рослин кількість рядів зерен була меншою, проте зерен в ряді більше і навпаки. Якщо максимальна різниця у варіантів за кількістю рядів була 1,1 шт., то різниця за кількістю зерен становила 18,0 шт. [10].

Виділення не вирішених раніше частин загальної проблеми. Для умов Лісостепу західного досі не встановлено зміни росту й розвитку рослин кукурудзи різних груп стиглості залежно від норм мінеральних добрив та мікродобрива, потребують обгрунтування питання параметрів лінійного росту рослин кукурудзи залежно від організованих фракторів.

Мета статті. Головною метою ціеї роботи є удосконалити агротехнічні заходи технології вирощування різностиглих гібридів кукурудзи в умовах Лісостепу західного, в т.ч. визначити показники структури врожаю, що впливають на продуктивність рослин.

Виклад основного матеріалу. Результати наших досліджень показали, що висо- та рослин досліджуваних гібридів коливалась в межах 263,2-277,1 см (контрольні варіанти). Найбільш високорослий гібрид у наших дослідах КВС 381. Висота рослин цього гібриду у розрізі варіантів коливалась в межах 274,3-294,5 см.

Досліджувані нами фрактори на висоту рослин впливали не суттево, проте у всіх досліджуваних гібридів на більших фронах добрив (250-300 кг/га) та при вищих нормах мікродобрив (2-3 л/га) спостерігалась тенденція до зміни показника у сторону збільшення залежно від гібриду і варіанту на 16-21,9 см. Поряд з цим, коефіціент варіації вказуе на те, що варіабельність в межах 2,2-3,1\% е низькою.

Висота кріплення качана сучасних гібридів дає змогу забезпечити належне збирання урожаю. Якщо у сортів та гібридів, які виведені більше 10 років тому, була проблема механізованого збирання за недостатньої кількості техніки та за висоти кріплення качана 30-50 см, то сучасні гібриди кукурудзи характеризуються висотою кріплення качанів в межах 90-120 см, що не створюе проблем при збиранні.

Досліджувані нами гібриди характеризувались значною висотою кріплення качана, а саме на контрольних варіантах у гібридів: КВС $2323-$ 95,2 см, КВС Кумпан - 121,1 см, КВС 381 - 112,1, КВС $4484-110,1$ см.

Важливими показниками структури урожаю зерна кукурудзи э кількість рядів та кількість зерен в ряді. Біометричний аналіз за показниками кількості рядів зерен та кількості зерен в ряду показав, що істотна різниця встановлена у розрізі гібридів. Так, на контрольних варіантах у гібридів кукурудзи кількість рядів і зерен в ряду була відповідно: КВС 2323 - 13,6 та 34,2 шт., КВС Кумпан - 12,0 i 33,1 шт., КВС 381 12,9 і 34,8 шт., КВC $4484-12,0$ та 34,0 шт.

Показник кількості рядів зерен у гібридів КВС 2323 та КВС 381 був дещо більшим, порівняно 3 гібридами КВС Кумпан та КВС 4484 , показник істотно коливався у розрізі варіантів. Максимальні показники кількості рядів зерен 16,8-16,9 шт. і кількості зерен в ряді качана кукурудзи 39,2 та 39,1 шт. була на варіантах норми добрив 300 кг/га та мікродобрива 2 і 3 л/га.

За тестом Дункана різниця за показником висоти рослин у розрізі досліджуваних гібридів кукурудзи була істотна, всі значення знаходились у різних гомогенних групах, середні значення за кожним гібридом коливались в межах 273,9-288,8 см, тобто різниця за висотою 3,3 см вже була достовірною (табл. 1).

Критерій Дункана за нормою добрив показав, що контрольний варіант (150 кг) віднесено до першої гомогенної групи, варіант 3 нормою 200 кг/га - до другої і варіанти із нормами 250 та 300 кг/га - до третьої групи, тобто не істотну різницю між собою показали варіанти 3 підвищеними нормами добрив (250 та 300 кг/га), проте 3 двома попередніми варіантами вони суттєво різнились за висотою (табл. 2).

Щодо впливу норм мікродобрива на висоту рослин гібридів кукурудзи виявлено достовірну різницю між варіантами без застосування та нормою 1 л/га та нормами 2 і 3 л/га, тобто значення розподілились у двох гомогенних групах (табл. 3). 
Таблиця 1

Залежність висоти рослин кукурудзи від гібриду за проведеним тестом Дункана, см (середне за 2018-2020 рр.)

\begin{tabular}{|c|l|c|c|c|c|c|}
\hline \multirow{2}{*}{ № } & \multirow{2}{*}{ Гібрид } & \multirow{2}{*}{ Висота рослин } & \multicolumn{5}{|c|}{ Гомогенні групи } \\
\cline { 4 - 7 } & & & $\mathbf{1}$ & $\mathbf{2}$ & $\mathbf{3}$ & $\mathbf{4}$ \\
\hline 1 & КВС Кумпан & 273,9 & $* * *$ & & & \\
\hline 2 & КВС 4484 & 281,6 & & $* * * *$ & & \\
\hline 3 & КВС 2323 & 285,6 & & & & $* * * *$ \\
\hline 4 & KВС 381 & 288,3 & & & & \\
\hline
\end{tabular}

Залежність висоти рослин кукурудзи від норми добрива

Таблиця 2 за проведеним тестом Дункана, см (середне за 2018-2020 рр.)

\begin{tabular}{|c|c|c|c|c|c|}
\hline \multirow{2}{*}{ № } & \multirow{2}{*}{$\begin{array}{c}\text { Норма добрива } \\
\text { (діамофоска), кг/га }\end{array}$} & \multirow{2}{*}{ Висота рослин } & \multicolumn{3}{|c|}{ Гомогенні групи } \\
\hline & & & 1 & 2 & 3 \\
\hline 1 & 150 & 274,4 & $* * *$ & & \\
\hline 2 & 200 & 279,3 & & $* * *$ & \\
\hline 3 & 250 & 287,1 & & & $* * *$ \\
\hline 4 & 300 & 288,5 & & & $* * *$ \\
\hline
\end{tabular}

Залежність висоти рослин кукурудзи від норми мікродобрива за проведеним тестом Дункана, см (середне за 2018-2020 рр.)

\begin{tabular}{|c|c|c|c|c|}
\hline \multirow{2}{*}{ № } & \multirow{2}{*}{ «орма мікродобрива } & \multirow{2}{*}{ «исота рослин } & $\mathbf{2}$ \\
\cline { 3 - 4 } & 1 & 279,6 & $* * *$ & $\mathbf{2}$ \\
\hline 1 & 0 & 279,8 & $* * *$ & $* * *$ \\
\hline 2 & 2 & 284,6 & & $* * *$ \\
\hline 4 & 3 & 285,4 & & \\
\hline
\end{tabular}

Науковими дослідженнями встановлено, що висота кріплення качанів кукурудзи знаходиться в тісній позитивні корелящійній залежності від висоти рослин. Висота рослин та кріплення качанів кукурудзи е невід'емними ознаками біологічних особливостей гібридів, проте ці показники дещо змінюються під впливом природних та технологічних чинників.

Проведений тест Дункана за показником висоти кріплення качана підтвердив тісні кореляційні залежності цього показника з висотою рослин досліджуваних гібридів, оскільки як і в таблиці 1 спостерігалась аналогічна тенденція розподілу за різними гомогенними групами, що доводить істотну різницю значень показника (табл. 4).

Щодо впливу норм добрив та мікродобрива на висоту кріплення качана кукурудзи за двома фракторами відмічено аналогічну тенденцію, за двома гомогенними групами розподілено варіанти норми добрива 150 та 200 кл/га і 250 та 300 кг/га, а також до першої групи віднесено варіант без мікродобрива і норму 1 л/га, а до другої вищі норми - 2 і 3 л/га (табл. 5, 6).

За тестом Дункана проведено аналіз впливу досліджуваних чинників на показник кількості рядів зерен, що має прямий вплив на формування продуктивності рослин. Середньофакторіальні значення розподілились наступним чином: середньоранній гібрид КВС Кумпан та середньостиглий КВС 4484, які в дослідах виявились менш продуктивними, віднесено до однієї гомогенної групи, та істотно різнились від них середньоранній гібрид КВС 2323 та середньостиглий КВС 381 , що розподілились у різних гомогенних групах, оскільки значення суттево різнились. Щодо впливу норм добрив та мікродобрив на формування кількості рядів у досліджуваних гібридів кукурудзи аналіз показав, що за всіма нормами добрив була істотна різниця по варіантах, а значення за нормами застосування мікродобрив розподілились за двома гомогенни-

Залежність висоти кріплення качана кукурудзи від гібриду

Таблиця 4 за проведеним тестом Дункана, см (середне за 2018-2020 рр.)

\begin{tabular}{|c|l|c|c|c|c|c|}
\hline \multirow{2}{*}{ № } & \multicolumn{1}{|c|}{ Гібрид } & Висота кріплення & \multicolumn{4}{|c|}{ Гомогенні групи } \\
\cline { 5 - 7 } & & кукурудзи & $\mathbf{1}$ & $\mathbf{2}$ & $\mathbf{3}$ & $\mathbf{4}$ \\
\hline 1 & КВС 2323 & 97,0 & $* * *$ & & & \\
\hline 2 & КВС 4484 & 111,7 & & & $* * *$ & \\
\hline 3 & КВС 381 & 112,9 & & & & $* * *$ \\
\hline 4 & КВС Кумпан & 113,9 & & & & \\
\hline
\end{tabular}


Залежність висоти кріплення качана кукурудзи від норми добрива за проведеним тестом Дункана, см (середне за 2018-2020 рр.)

\begin{tabular}{|c|c|c|c|c|}
\hline \multirow{2}{*}{ № } & \multirow{2}{*}{ Норма добрива } & Висота кріплення & \multicolumn{2}{|c|}{ Гомогенні групи } \\
\cline { 3 - 4 } & (діамофоска), кг/га & кукурудзи & $\mathbf{1}$ & $\mathbf{3}$ \\
\hline 1 & 150 & 107,9 & $* * *$ & $* * *$ \\
\hline 2 & 200 & 108,3 & & $* * *$ \\
\hline 3 & 250 & 109,5 & & $* * *$ \\
\hline
\end{tabular}

Таблиця 6

Залежність висоти кріплення качана кукурудзи від норми мікродобрива за проведеним тестом Дункана, см (середне за 2018-2020 рр.)

\begin{tabular}{|c|c|c|c|c|}
\hline \multirow{2}{*}{ № } & \multirow{2}{*}{$\begin{array}{l}\text { Норма мікродобрива } \\
\text { «Урожай зерно», л/га }\end{array}$} & \multirow{2}{*}{$\begin{array}{c}\text { Висота кріплення } \\
\text { кукурудзи }\end{array}$} & \multicolumn{2}{|c|}{ Гомогенні групи } \\
\hline & & & 1 & 2 \\
\hline 1 & 0 & 108,4 & $* * *$ & \\
\hline 2 & 1 & 108,5 & $* * *$ & \\
\hline 3 & 3 & 109,2 & & $* * *$ \\
\hline 4 & 2 & 109,3 & & $* * *$ \\
\hline
\end{tabular}

ми групами, до першої належали варіанти без мікродобрива та 3 нормою 1 л/га, а до другої з нормами 2 і 3 л/га.

На сьогоднішній день, коли погодні умови $€$ нестабільними у розрізі років практично у всіх зонах вирощування кукурудзи можна використовувати метод прогнозування урожайності ще у фразі молочної стиглості зерна. Для цього маючи фоктичну густоту рослин, кількість качанів на рослині, кількість рядів в качані та кількість зерен в ряді можна спрогнозувати урожайність та визначити, які саме компоненти потерпають від стресів.

Середньофакторіальні значення кількості зерен в ряду у розрізі гібридів коливались в межах 34,36-36,86 штук. Різниця між гібридами становила від 0,52 до 2,5 штук, проте значення усіх чотирьох гібридів знаходились у різних гомогенних групах, що свідчить про істотну різницю між ними за показником кількості зерен в ряду. Тест Дункана показав, що достовірну різницю за показником кількості зерен в ряду качана кукурудзи підтверджено між варіантами норм добрив
150 і 200 кг/га та 250 і 300 кг/га, оскільки значення розподілено за двома гомогенними групами.

Як і на варіантах 3 макродобривом, так і на варіантах із застосуванням мікродобрив спостерігалась схожа тенденція за розподілом у гомогенних групах, тобто значення двох менших норм - у першій групі, а двох більших норм у другій. Мінімальне середньофакторіальне значення становило 35,05 штук, максимальне 35,91 штук.

Висновки і пропозиції. Біометричний аналіз показав, що найбільш високорослий гібрид у наших дослідах - КВС 381. Висота рослин цього гібриду у розрізі варіантів коливалась в межax 274,3-294,5 см. Досліджувані нами гібриди характеризувались значною висотою кріплення качана, a саме на контрольних варіантах у гібридів: КВС 2323 - 95,2 см, КВС Кумпан 121,1 см, КВС 381 - 112,1, КВС 4484 - 110,1 см. Максимальні показники кількості рядів зерен 16,8-16,9 шт і кількості зерен в ряді 39,2 та 39,1 шт була на варіантах норми добрив 300 кг/га та мікродобрива 2 і 3 л/га.

\section{Список літератури:}

1. Лавриненко Ю.О., Вожегова Р.А., Коковіхін С.В. та ін. Кукурудза на зрошуваних землях півдня України. Херсон : Айлант, 2011. 468 с.

2. Лебідь Л. Повернення королеви полів. Аграрний тиждень. 2013. № 14-15. С. 22.

3. Маслак О. Переваги - за кукурудзою. Пропозиція. 2013. № 5(215). С. 32-34.

4. Коваленко О.А., Ковбель А.І. Вплив елементів живлення на стресовий стан польових культур. Агронол. 2013. № 2. C. 24-27.

5. Сатановська І.П. Вплив обробки насіння та позакореневих підживлень на біометричні показники рослин кукурудзи. Корми і кормовиробнищтво. 2013. Вип. 75. С. 62-67.

6. Лавриненко Ю.О., Гож О.А. Ріст і розвиток рослин гібридів кукурудзи ФАО 180-430 за впливу регуляторів росту і мікродобрив в умовах зрошення на Півдні України. Збірник наукових праць «Зрошуване землеробство». 2016. № 65. С. 128-131.

7. Лавриненко Ю.О., Коковіхін С.В., Писаренко П.В. Екологічна мінливість показників темпів розвитку рослин кукурудзи. Таврійський науковий вісник : зб. наук. пр. Херсон : Айлант, 2005. Вип. 40. С. $46-55$.

8. Паламарчук В.Д. Вплив застосування бактеріального добрива «Біомаг» на продуктивність гібридів кукурудзи. Збірник наукових пращь ВНАУ. 2012. № 63. Вип. 4. С. 14-22.

9. Мазур В.А., Циганська О.І., Шевченко Н.В. Висота рослин кукурудзи залежно від технологічних прийомів вирощування. Сільське господарство та лісівництво. Рослинниитво, сучасний стан та перспективи розвитку. 2018. № 8. C. 5-13.

10. Багатченко В.В., Таганцова М.М., Стефківська Ю.Л. Вплив густоти стояння рослин кукурудзи на насінневу продуктивність батьківських компонентів гібридів Zea mays L. Наукові праці інституту біоенергетичних культур і иукрових буряків. 2018. Вип. 26. С. 56-66. 


\section{References:}

1. Lavrynenko Iu.O., Vozhehova R.A., Kokovikhin S.V. (2011) Kukurudza na zroshuvanykh zemliakh pivdnia Ukrainy [Corn on irrigated lands of southern Ukraine]. Kherson: Aylant, $468 \mathrm{p}$.

2. Lebid L. (2013) Povernennia korolevy poliv [Return of the Queen of Fields]. Ahrarnyi tyzhden, vol. 14-15, p. 22.

3. Maslak O. (2013) Perevahy - za kukurudzoiu [Advantages - for corn]. Propozytsiia, vol. 5(215), pp. 32-34.

4. Kovalenko O.A., Kovbel A.I. (2013) Vplyv elementiv zhyvlennia na stresovyi stan polovykh kultur [Influence of nutrients on the stressful state of field crops]. Ahronom, vol. 2, pp. 24-27.

5. Satanovska I.P. (2013) Vplyv obrobky nasinnia ta pozakorenevykh pidzhyvlen na biometrychni pokaznyky roslyn kukurudzy [Influence of seed treatment and foliar fertilization on biometric indicators of maize plants]. Kormy $i$ kormovyrobnytstvo, issue 75 , pp. 62-67.

6. Lavrynenko Yu.O., Hozh O.A. (2016) Rist i rozvytok roslyn hibrydiv kukurudzy FAO 180-430 za vplyvu rehuliatoriv rostu i mikrodobryv v umovakh zroshennia na Pivdni Ukrainy [Growth and development of FAO maize hybrid plants 180-430 under the influence of growth regulators and microfertilizers under irrigation conditions in the South of Ukraine]. Zbirnyk naukovykh prats "Zroshuvane zemlerobstvo", vol. 65, pp. 128-131.

7. Mazur V.A., Tsyhanska O.I., Shevchenko N.V. (2018) Vysota roslyn kukurudzy zalezhno vid tekhnolohichnykh pryiomiv vyroshchuvannia [The height of corn plants depending on the technological methods of cultivation]. Silske hospodarstvo ta lisivnytstvo. Roslynnytstvo, suchasnyi stan ta perspektyvy rozvytku, vol. 8, pp. 5-13.

8. Lavrynenko Yu.O., Kokovikhin S.V., Pysarenko P.V. (2005) Ekolohichna minlyvist pokaznykiv tempiv rozvytku roslyn kukurudzy [Ecological variability of maize plant growth rates]. Tavriiskyi naukovyi visnyk: zb. nauk. pr. Kherson: Ailant, issue 40, pp. 46-55.

9. Palamarchuk V.D. (2012) Vplyv zastosuvannia bakterialnoho dobryva «Biomah» na produktyvnist hibrydiv kukurudzy [Influence of application of bacterial fertilizer "Biomag" on productivity of hybrids of corn]. Zbirnyk naukovykh prats VNAU, vol. 63, issue 4, pp. 14-22.

10. Bahatchenko V.V., Tahantsova M.M., Stefkivska Yu.L. (2018) Vplyv hustoty stoiannia roslyn kukurudzy na nasinnievu produktyvnist batkivskykh komponentiv hibrydiv Zea mays L. [Influence of standing density of maize plants on seed productivity of parent components of Zea mays L. hybrids]. Naukovi pratsi instytutu bioenerhetychnykh kultur i tsukrovykh buriakiv, issue 26, pp. 56-66. 